\title{
PELATIHAN PEMBUATAN ABON IKAN GABUS DI KAMPUNG SARMAYAM INDAH DISTRIK TANAH MIRING KABUPATEN MERAUKE
}

\author{
Wahida $^{1 \star}$, Sunarni ${ }^{2}$, Rosmala Widijastuti ${ }^{3}$ \\ ${ }^{1} J u r u s a n$ Teknik Pertanian, Universitas Musamus Merauke \\ ${ }^{2}$ Jurusan Manajemen Sumberdaya Perairan, Universitas Musamus Merauke \\ ${ }^{3}$ Jurusan Agroteknologi, Universitas Musamus Merauke \\ *Korespondensi: wahida@unmus.ac.id
}

\begin{abstract}
ABSTRAK
Masyarakat kampung Sarmayam Indah memanfaatkan ikan gabus sebagai ikan konsumsi dengan cara dibakar dan dimasak sehingga tidak dapat bertahan lama. Sehingga perlu dilakukan pengolahan ikan gabus agar lebih bisa bertahan lama dan mempunyai nilai ekonomis yang tinggi. Salah satu cara untuk mengembangkan pengolahan ikan gabus yakni menjadi Abon. Metode pelaksanaan terdiri dari tahap sosialisasi dan pelatihan pembuatan abon ikan. Kegiatan dilaksanakan bulan November 2018. Dengan adanya kegiatan sosialisasi dan Pelatihan pembuatan abon ikan di kampung Sarmayam Indah distrik Tanah Miring kabupaten Merauke masyarakat yang ada di kampung tersebut terutama ibu-ibu rumah tangga memperoleh pengetahuan dan keterampilan dalam mengolah ikan gabus terutama dalam pembuatan abon ikan gabus.
\end{abstract}

Kata Kunci; Abon, Ikan Gabus, Pengolahan.

\section{PENDAHULUAN}

Wilayah Kabupaten Merauke sebagian besar termasuk wilayah datar dengan ketinggian 0 - 40 meter dpl, bahkan sebagian wilayah berada di bawah permukaan laut sehingga bentangan daerah pasang surut sampai mencapai 200 kilometer ke arah daratan. Bentang alam yang luasnya mencapai $45.071 \mathrm{~km}^{2}$, sementara jumlah penduduk yang relatif sedikit yakni hanya 175.389 jiwa dan kepadatan penduduk hanya 4,2 jiwa per $\mathrm{km}^{2}$. Sebaran wilayah Merauke yang sebagian besar berupa hutan, rawa dan lahan kosong. Sumberdaya air dan alam yang masih melimpah dan jumlah penduduk yang relatif kecil sehingga ketersediaan ikan secara alamiah hampir tersedia sepanjang waktu utamanya musim hujan.

Salah satu jenis ikan yang banyak ditemukan di daerah rawa yaitu ikan gabus (Channa striata) yang sering diistilahkan dengan nama Gastor telah berkembang pesat ke seluruh perairan perikanan darat (hutan, rawa). Sementara hasil tangkapan ikan gastor yang dilakukan masyarakat setempat hanyalah digunakan untuk memenuhi kebutuhan konsumsi harian masyarakat lokal. Berdasarkan pengamatan di lapangan menunjukkan bahwa ikan gastor dinilai ikan yang harganya murah, maka salah satu upaya untuk meningkatkan nilai jual diperlukan adanya penerapan teknologi untuk meningkatkan nilai tambah. Upaya meningkatkan nilai tambah dengan cara memberikan sentuhan teknologi sehingga ikan gabus dapat dibuat menjadi abon ikan. Selain meningkatkan nilai tambah juga diharapkan mampu untuk meningkatkan citra produk ikan gabus yang bergizi tinggi.

Abon merupakan produk olahan yang sudah cukup dikenal luas oleh masyarakat. Dewan Standarisasi Nasional (1995) mendefinisikan abon sebagai suatu jenis makanan kering berbentuk khas yang terbuat dari daging yang direbus, disayat- 
sayat, dibumbui, digoreng dan dipres. Pembuatan abon menjadi alternative pengolahan ikan dalam rangka penganekaragaman produk perikanan dan mengantisipasi melimpahnya tangkapan ikan di masa panen.

Abon ikan merupakan jenis makanan olahan ikan yang diberi bumbu, diolah dengan cara perebusan dan penggorengan. Produk yang dihasilkan mempunyai bentuk lembut, rasa enak, baukhas, dan mempunyai daya awet yang relatif lama. Sementara menurut Karyono dan Wachid (1982), abon ikan adalah produk olahan hasil perikanan yang dibuat dari daging ikan, melalui kombinasi dari proses penggilingan, penggorengan, pengeringan dengan cara menggoreng, serta penambahan bahan pembantu dan bahan penyedap terhadap daging ikan. Seperti halnya produk abon yang terbuat dari daging ternak, abon ikan cocok pula dikonsumsi sebagai pelengkap makan roti ataupun sebagai lauk-pauk.

Sampai saat ini, di Kabupaten Marauke khususnya masyarakat yang ada di kampung Sarmayam Indah hanya memanfaatkan ikan Gastor sebagai ikan konsumsi dengan cara dibakar dan dimasak sehingga tidak dapat bertahan lama. sehingga perlu dilakukan pengolahan ikan Gastor agar lebih bisa bertahan lama dan mempunyai nilai ekonomis yang tinggi. Salah satu cara untuk mengembangkan pengolahan ikan gastor yakni menjadi Abon.

\section{METODE PELAKSAAN}

\section{A. Waktu dan Tempat}

Pelaksanaan kegiatan pengabdian tentang pelatihan pembuatan abon ikan di Kampung Sarmayam Indah Distrik Tanah Miring Kabupaten Merauke dilakukan pada bulan November 2018, di Balai Kampung Sarmayam Distrik Tanah Miring Kabupaten Merauke.

\section{B. Tahap Pelakasanaan}

Tahapan pelaksanaan kegiatan meliputi sosialisasi dan pelatihan pembuatan abon ikan gastor, di kampung Sarmayam Indah. Hal ini dilakukan untuk mneningkatkan pengetahuan dan keterampilan kepada ibu-ibu rumah tangga yang ada dikampung Sarmayam Indah. Selanjutnya diajarkan tentang tata cara membuat Abon ikan Gastor. Proses pembuatan abon ikan relatif mudah sehingga bisa langsung dikerjakan oleh anggota keluarga sendiri. Peralatan yang dibutuhkan pun relatif sederhana sehingga untuk memulai usaha ini relatif tidak memerlukan biaya investasi yang besar. Oleh sebab itu, usaha pengolahan abon ikan ini bisa dilakukan dalam skala usaha kecil. Hal ini membuat usaha ini sangat berpotensi untuk dikembangkan di banyak wilayah di Indonesia yang memiliki sumberdaya perikanan laut yang melimpah. Proses pembuatan abon ikan relatif sederhana dan mudah dilakukan. Secara umum proses pembuatan abon ikan gastor adalah sebagai berikut :

a. Pengadaan Bahan Baku

Bahan baku yang digunakan adalah ikan Gastor yang masih utuh dan segar, untuk selanjutnya dilakukan proses penyiangan. 
b. Penyiangan Bahan Baku

Pada proses penyiangan yaitu pemotongan ikan dan pencucian daging ikan. Bagian kepala, isi perut dan sirip ikan dibuang. Daging ikan hasil tahap penyiangan sebaiknya direndan dalam air yang dicampur dengan air cuka/air perasan jeruk nipis. Kadar air cuka yang dipakai adalah $\pm 2 \%$. Ini dilakukan untuk membuat bau amis hilang.

c. Perebusan

Potongan ikan yang telah direndam dalam air cuka kemudian disusun ke dalam badeng dan direbus selama 30 - 60 menit. Proses perebusan akan dihentikan setelah daging ikan menjadi lunak. Selama proses perebusan tersebut juga ditambahkan daun salam dan garam rebus.

d. Pengepresan I

Ikan yang telah direbus kemudian dipres dengan mesin pengepres atau menggunkan kain. Sebelum dipres, daging ikan tersebut sebaiknya ditiriskan terlebih dahulu sekitar 5 - 10 menit. Tahap pengepresan bertujuan untuk mengurangi kadar air pada daging ikan yang telah direbus. Makin sedikit kadar air yang dikandung dalam daging, maka akan makin baik pula serat-serat daging yang dihasilkan.

e. Pencabikan I

Setelah daging ikan dipres, kemudian dilakukan proses pencabikan sampai menjadi serat.-serat. Proses ini bisa dilakukan dengan tangan.

f. Pemberian bumbu dan Santan

Pada tahap ini, serat-serat daging hasil pencabikan ditambahkan bahan-bahan pembantu (bumbu-bumbu). Bumbu-bumbu yang ditambahkan terdiri dari : bawang putih, bawang merah, lada, gula pasir, ketumbar, daun jeruk, sereh, lengkuas, garam dapur. Semua bumbu dihancurkan dengan menggunkan blender.

g. Pemasakan

Santan kelapa dimasak sampai hampir menjadi minyak, masukkan ikan yang sudah dicampur dengan bumbu yang sudah diblender, aduk sampai rata. Aduk terus terus sampai kering atau berwarna coklat.

h. Pengepresan II

Tahap produksi berikutnya adalah pengepresan kembali serat-serat daging ikan yang telah masak. Proses pengepresan tahap kedua ini bertujuan untuk mengurangi kadar minyak pasca proses pemasakan.

i. Pencabikan II

Setelah dipres, kemudian dilakukan pencabikan tahap kedua agar tidak terjadi penggumpalan. Proses pencabikan tahap kedua ini akan dihentikan setelah terbentuk produk akhir berupa abon ikan dengan tekstur yang seragam.

j. Pengemasan

Pada tahap akhir produksi dilakukan pengemasan abon ikan. Jika pengemasan tidak langsung dilakukan, maka produk abon ikan akan disimpan terlebih dahulu dalam kantung plastik besar di tempat penyimpanan, sebelum dilakukan pengemasan. 


\section{HASIL DAN PEMBAHASAN}

Kegiatan pelatihan pembuatan abon ikan di kampung Sarmayam Indah distrik Tanah Miring Kabupaten Merauke dilaksanakan pada tanggal 04 November 2018. Yang dihadiri oleh ibu-ibu rumah tangga yang ada di kampung Sarmayam. Masyarakat yang ada di kampung Sarmayam sebagian besar berasal dari jawa dan hanya sebagian kecil masyarakat lokal, namun mereka hidup rukun dan damai serta saling bekerjasama. Kebiasaan sehari hari masyarakat yang ada di kampung Sarmayam adalah petani dan mencari ikan di sungai. Jenis-jenis ikan yang paling banyak ditangkap oleh masyarakat setempat adalah ikan gastor, ikan betik dan ikan mujair.

Sebagian besar ikan hasil tangkapan langsung dikonsumsi dan ada yang diolah menjadi ikan asin. kebanyakan masyarakat tidak memakan ikan gastor namun dijadikan ikan asin untuk dijual. Dengan adanya kegiatan ini masyarakat kampung Sarmayam bisa mengolah ikan gastor menjadi produk olahan lain selain ikan asin.

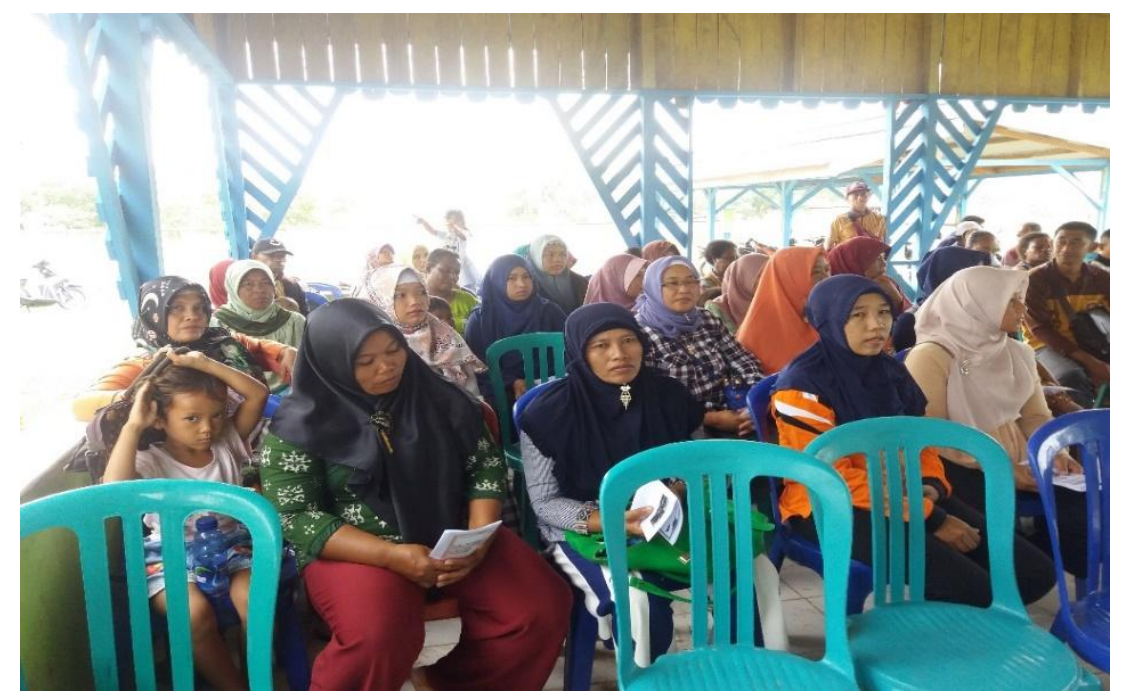

Gambar 1. Peserta Kegiatan Pengabdian

Pelaksanaan kegiatan pengabdian dilakukan di balai kampung, pada saat kami dan rombongan tiba masyarakat yang ada di kampung Sarmayam sudah berkumpul di balai kampung. Kegiatan selanjutnya yakni persiapan pelaksanaan kegiatan namun sebelumnya kami berdiskusi singkat dengan kepala kampung untuk mengatur jalannya kegiatan tersebut.

Kami rombongan tim bersama dengan warga mulai menyiapkan peralatan yang akan digunakan selama kegiatan berlangsung, setelah semua siap maka acara dibuka oleh ketua tim untuk menyampaikan maksud dari kegiatan ini dan mengucapkan terimakasih kepada warga yang telah bersedia untuk mengikuti kegiatan ini. Kegiatan selanjutnya yaitu pembagian brosur yang dilakukan oleh ketua tim dan anggota yang terdiri dari para dosen dan mahasiswa yang ikut dalam kegiatan tersebut. 


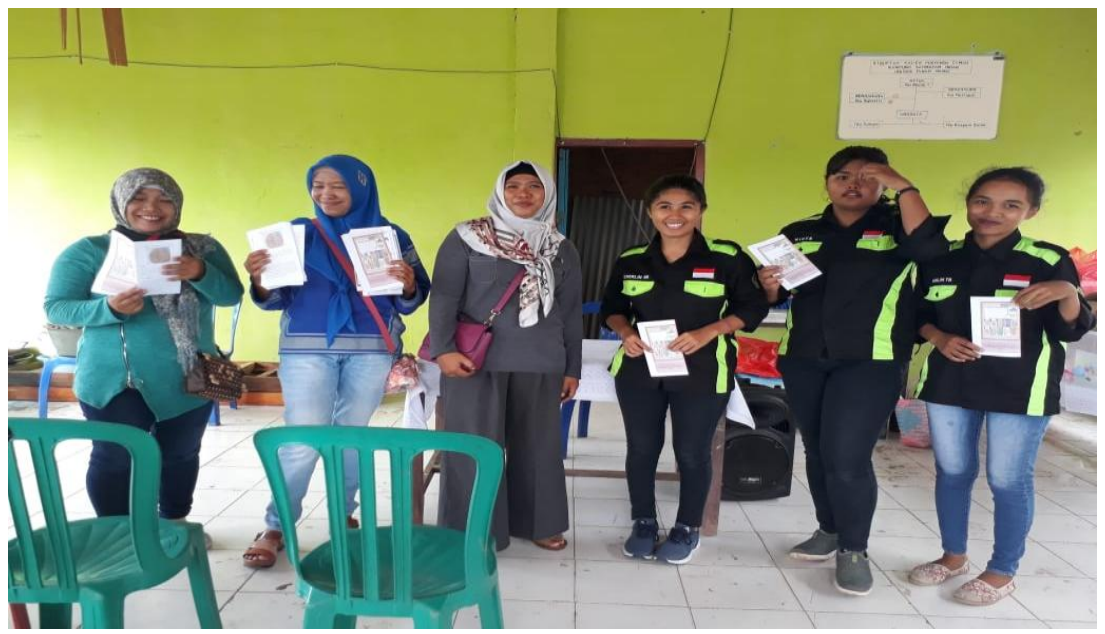

Gambar 2. Penyampaian Materi dan Pembagian Brosur.

Setelah tim memberikan brosur kepada peserta kegiatan brosur yang diberikan berisi tentang prosedur pembuatan abon ikan gastor. Selanjutnya tim mengajak para peserta pelatihan untuk bersama - sama dalam proses pembuatan abon ikan gastor. Dari hasil pengamatan kami masyarakat kampung sarmayam sangat antusias dalam mengikuti kegiatan ini, tanpa menunggu lebih lama para peserta langsung mengambil dan menyiapkan bahan dan peralatan sambil berdiskusi dengan tim pengabdian.

Kegiatan pertama yang akan dilakukan yakni pembuatan abon ikan gastor. Langkah pertama membersihkan ikan gastor lalu dikukus, sambil menunggu ikan gastor matang para peserta mulai mempersiapkan bumbu dan santan. Pada saat menyiapkan bumbu ternyata ada yang kurang yakni lengkuas, kami dari tim meminta bantuan kepada peserta kegiatan dimana kita bisa mendapatkan lengkuas tersebut, kemudian salah satu peserta mengatakan bahwa dirumahnya kebetulan menanam tanaman lengkuas dengan senang hati kami dari tim langsung meminta peserta untuk mengambilnya. Setelah semua siap dan ikan yang dikukus sudah matang, langkah selanjutnya merebus santan kelapa. Ikan yang sudah matang kemudian dipisahkan dari duri-durinya. Setelah santan mendidih dan hampir menjadi minyak lalu masukkan daging ikan dicampur dengan bumbu yang sudah dihaluskan. Aduk hingga berwarna kecoklatan.
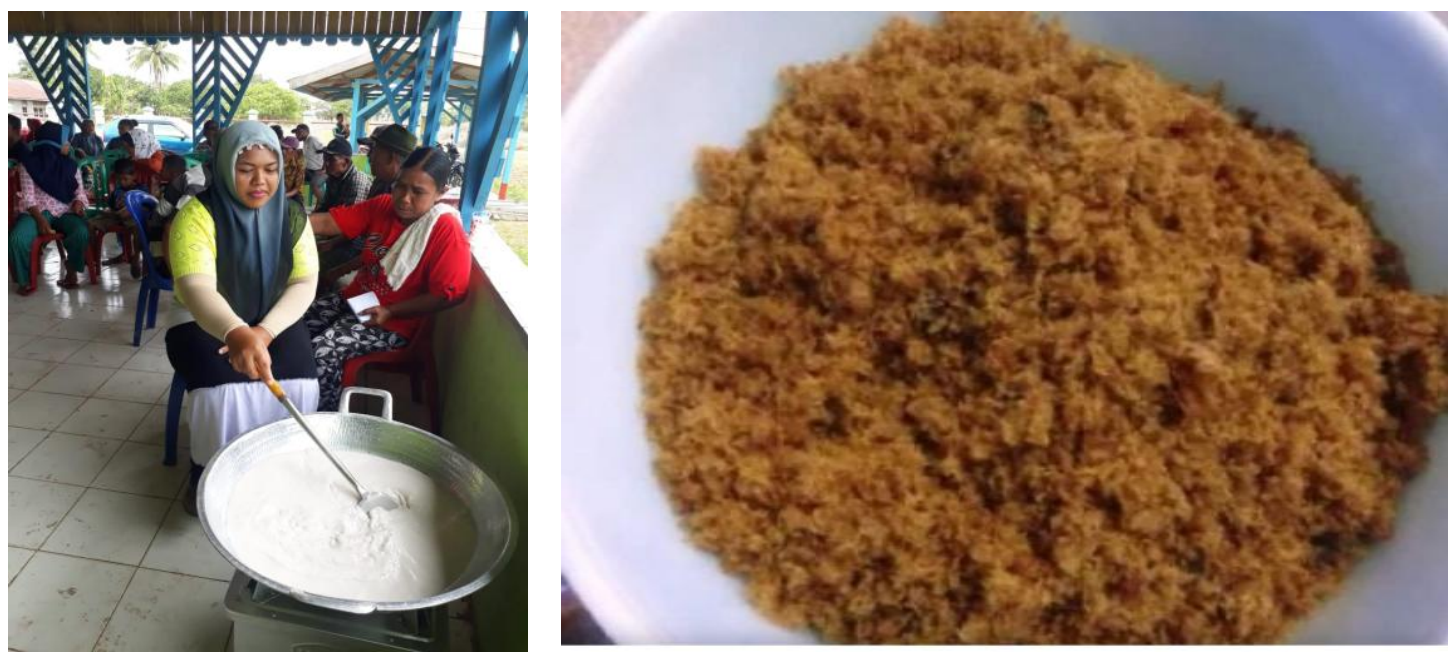

Gambar 3. Pembuatan Abon Ikan Gastor 
Banyak dari peserta kegiatan tidak mau mengkonsumsi ikan gastor dikarenakan bentuknya seperti ular, tetapi setelah diolah menjadi abon ikan para beserta mau mencoba dan merasakan hasil masakannya dan mengatakan ternyata enak serta tidak berasa ikan gastor lagi.

Setelah selesai kegiatan tim pengabdian menyerahkan hasil olahan dari ikan gastor kepada bapak kepala kampung Sarmayam selanjutnya untuk dinikmati secara bersama-sama dengan para peserta kegiatan pengabdian. Pada akhir kegiatan tim pengabdian mengucapkan terimakasih kepada Bapak kepala kampung dan masyarakat yang ada di kampung Sarmayam telah menerima kita dan kegiatan ini telah berjalan dengan lancar hingga kegiatan ini berakhir. Saran dari masyarakat kampung Sarmayam mengharapkan kembali kehadiran kami tim pengabdian untuk mengadakan kegiatan pelatihan dengan topik yang berbeda agar masyarakat lebih mengenal lagi berbagai macam bentuk olahan ikan yang lainnya.

\section{KESIMPULAN DAN SARAN}

\section{A. Kesimpulan}

Dengan adanya kegiatan sosialisasi dan Pelatihan pembuatan abon ikan di kampung Sarmayam Indah distrik Tanah Miring kabupaten Merauke masyarakat yang ada di kampung tersebut terutama ibu-ibu rumah tangga memperoleh pengetahuan dan keterampilan dalam mengolah ikan gastor terutama dalam pembuatan abon ikan. Dalam pelaksanaan pelatihan para ibu-ibu juga terlibat dalam proses pembuatan hal ini kami lakukan agar ibu-ibu tidak hanya melihat dan mendengarkan saja tetapi juga ikut terlibat dalam proses pembuatan sehingga lebih mudah diingat dan dipraktekkan di rumah.

\section{B. Saran}

Perlu diadakannya pengabdian lanjutan tentang pendampingan masyarakat kampung Sarmayam tentang produk olahan ikan yang lain agar meningkatkan keterampilan para ibu-ibu rumah tangga dalam mengolah ikan.

\section{DAFTAR PUSTAKA}

Badan Standarisasi Nasional. 1995. SNI 01-37071995 Abon . Jakarta : Badan Standarisasi Nasional.

Badan Pusat Statistik Kabupaten Merauke. 2008. Merauke Dalam Angka. Penerbit CV. Mitra Karya Pura. BPS Kabupaten Merauke.

Karyono dan Wachid. 1982. Petunjuk Praktek Penanganan dan Pengolahan Ikan. Jakarta: Departemen Pendidikan dan Kebudayaan. 